\title{
WYKRES GORĄCZKI III RP
}

\author{
Piotr Semka
}

O ile przed rokiem '89 Jakub Karpiński był badaczem studium choroby i wykresu gorączki, która trawiła ustrój, o tyle po roku ' 89 był wnikliwym obserwatorem tego, jak pamięć o PRL-u w III RP podlega rozmaitym chorobom.

Od 1997 roku Jakub Karpiński zaczął pisać teksty, w których stawiał pytanie o to, jak pamiętamy PRL. Był człowiekiem łączącym w sobie zdziwienie nienormalnością komunizmu z głębokim przekonaniem, że badanie komunizmu i jego patologii jest najlepsza formą antykomunizmu. To właśnie doskonale korespondowało z jego umiarem i stylem ironisty. Często używał określeń „być może”, ,wydaje się”. Była to naturalna reakcja na PRL, w którym przywódcy państwa mówili o wszystkim jako o pewniku. Zaczęło się od tego, że sukces komunizmu miał być w ogóle pewnikiem naukowym. Studia Jakuba nad komunizmem przypominały obserwację cudzoziemców, którzy w XVIII czy XIX wieku zawsze się dziwili, że gdy wszyscy w jakiejś karczmie czy przy okazji jakiejś uroczystości wybuchają chóralnym śmiechem, to Anglicy zachowują kamienną twarz. A z kolei gdy jest bitwa morska i fruwaja kartacze, to wtedy brytyjscy dżentelmeni właśnie z uśmiechem demonstrują, że są w swoim żywiole. I w tym sensie Jakub Karpiński był najbardziej dolegliwy dla komunistów, gdy krzywił usta w szyderstwie, kiedy potrafił dokładnie zanalizować, na czym polega kłamliwość rozmaitych gier prowadzonych przez komunistyczne władze.

Symbolem jego angielskiego dystansu był choćby tytuł książki opisującej jego wyrok w procesie taterników - Taternictwo niz̨inne. To jest właśnie cały Jakub Karpiński! I to jest człowiek, który za to też płacił wysoką cenę, ponieważ tak naprawdę nienawiść reżimu do Karpińskiego przed rokiem '89 odbywała się w dosyć prymitywnej formie procesu, w którym próbowano go poniewierać, a potem zakazano wjazdu do Polski. Ale trzeba też wyraźnie powiedzieć, że po '89 roku z powodu tej ironii, tego czegoś, co można nazwać socjologia pamięci III RP, czyli socjologią niepokoju mo- 
ralnego, był po cichu nielubiany przez wielu ludzi. Tych wszystkich ludzi teksty Jakuba Karpińskiego denerwowały, a potem drażniły ich także po '89 aż do jego śmierci w 2003 roku. W tym sensie można powiedzieć, że był to człowiek, który kojarzy mi się z dwoma innymi tytanami ducha, jak Zbigniew Herbert i Gustaw Herling-Grudziński. Otóż wszyscy oni także po '89 roku przeżywali kolejne zdziwienia. Zdziwienie lustracją, zdziwienie powrotem postkomunistów do władzy, zdziwienie tezami o tym, że wszyscy jesteśmy umoczeni w komunizm, zdziwienie rozkładaniem komunizmu na czynniki pierwsze pod hasłem, że nie był to totalitaryzm. Jakubowi Karpińskiemu zdarzało się tylko parę razy wymieniać z nazwiska swoich adwersarzy i mam wrażenie, że był to sygnał wyjątkowego rozdrażnienia. Bardzo charakterystyczny jest tytuł tekstu Jakuba Karpińskiego w „Rzeczpospolitej” z 1999 roku: „Czy w ogóle był tu jakiś komunizm?”. Punktem wyjścia do napisania tego artykułu stała się wydana wówczas Czarna ksiega komunizmu, ale już sam tytuł pokazuje bardzo dobrze ten stan niepokoju moralnego Jakuba Karpińskiego. W tekście tym pisał on:

Słychać głosy, że nie należy komunizmu redukować do zbrodni. Czyli że było w nim coś jeszcze oprócz zbrodni, to jest prawda. W każdym zbrodniarzu jest coś jeszcze oprócz zbrodni. Trzeba czasem odetchnać, trudno zajmować się zbrodnią nieustannie (Karpiński 1999a).

To jest pióro doskonałego ironisty. Czytając jego tekst, ma się wrażenie umiejętności przełożenia koszmaru komunizmu na lekkość pióra, jak udawało się to tylko w wypadku Macieja Rybińskiego. Podam inny przykład:

Zwolennicy komunizmu niekiedy przenoszą dyskusję w strefę wyobrażeń. Piszą, że nie można wyobrazić sobie nazizmu bez komór gazowych, natomiast można sobie wyobrazić komunizm bez Gułagu. Poruszanie się wśród wyobrażeń zależy od wyobraźni. Nazizm przez większość swego trwania istniał bez komór gazowych, zdarzało się też, że komunizm istniał bez Gułagu. Ale osłabienie działań Gułagu przyczyniło się do likwidacji komunizmu. Komunizm przestał istnieć, gdy zrezygnował z przemocy (do końca wahano się, czy z niej zrezygnować). [...] W porównaniach ideologii komunistycznej i narodowo-socjalistycznej zwraca się niekiedy uwagę na antyhumanitarny charakter nazizmu i humanitarny ponoć charakter komunizmu, gdy 
poprzestać na treści ideologii. [...] Komunizm kłamał podobno bardziej niż narodowy socjalizm. Dokładniejsze przyjrzenie się obydwu ideologiom i praktykom propagandowym nie pozwala na podtrzymanie tych stwierdzeń.. Obydwie ideologie formułowały wzniosłe i mętne cele, mówiły o kształtowaniu lepszego człowieka i o konieczności radykalnej zmiany dotychczasowych, zgniłych i zepsutych warunków społecznych. Proponowanym środkiem była w obydwu ideologiach przemoc wobec wrogów (Karpiński 1999a).

Bardzo dobrym przykładem tego jest porównanie poczynione między kaptowaniem księży w latach stalinowskich i kaptowaniem w latach 70. Oczywiście jest różnica pomiędzy wyrywaniem paznokci a wyciąganiem paszportu z gotową wizą na studia na Uniwersytecie Papieskim w Rzymie i chowaniem jej po chwili z tajemniczym uśmiechem. Ale ta deprawacja psychiczna była w obu wypadkach równa.

Oto zobaczmy, co Jakub ironista wyłapał z audycji Janusza Weissa „Dzwonię do Pani/Pana w bardzo nietypowej sprawie”. To jest tekst z „Rzeczpospolitej” z lutego 1999 roku:

Czym była PZPR, czym była PRL, jest niezależne od poglądów ludzi w tej sprawie. Aby odpowiedzieć na to pytanie, czym była PZPR, [...] pożyteczne mogą być porównania i wskazanie instytucji pełniącej podobne funkcje. W Radiu ZET Janusz Weiss rozmawiał ostatnio z taksówkarzem, występującym przeciwko mafii taksówkowej stacjonującej przy lotnisku Okęcie. „A skąd pan tyle wie o obyczajach mafii?” - zapytał Janusz Weiss. Taksówkarz odpowiedział: „Kiedyś do niej należałem, więc wiem”. Mówił, że przynależność do mafii była korzystna. Mafia była instytucją ubezpieczeniową, działała jak firma ochroniarska. Za ochronę można było płacić pieniędzmi, ale można było też wkupić się posłuszeństwem (Karpiński 1999b).

Jakub Karpiński zwracał uwagę, że analogie są uderzające. Gdy PZPR istniała, przynależność do niej zwiększała szanse kariery. PZPR budowała socjalizm i stała na straży, a jednocześnie chroniła swoich członków przed niebezpieczeństwami, dawała im szansę. Gdy w roku 1997 Aleksander Kwaśniewski powiedział gdzieś, że nie wstapił do „Solidarności”, bo był to barani pęd, który był dla niego jako estety obrzydli- 
wy, pamiętam, że ktoś mi opowiadał, jak Jakub Karpiński skomentował te słowa: „trudno o bardziej kłamliwą rzecz”. Po prostu Kwaśniewski 13 grudnia uzyskał utrwalenie swojej wyjątkowej pozycji. Mógł korzystać ze sklepów za firankami, mógł wyjeżdżać bez żadnych problemów, mógł korzystać ze znacznie lepszych stołówek w KC PZPR, mógł być ministrem, mógł polecieć na olimpiadę w Seulu. Przecież tego wszystkiego po 13 grudnia nie było. Gdyby Solidarność trwała, to być może Aleksander Kwaśniewski zderzyłby się właśnie z Jakubem Karpińskim, który by wtedy wrócił z emigracji i być może zająłby w społeczeństwie wyższe stanowisko. Ta obserwacja Jakuba Karpińskiego jest oczywiście bardzo trafna jako przykład analizy dużej nostalgii za PRL-em.

Przypomina mi się pewna obserwacja Jakuba, którą pamiętam z rozmów. Zwracał on uwagę, że bardzo charakterystyczna jest różnica, z jaką „Gazeta Wyborcza” przedstawiała wyniki badań dwóch różnych tematów. Otóż w pierwszym wypadku, gdy „Gazeta Wyborcza” porusza problem polskiej pamięci historycznej, a szczególnie polskiej pamięci o relacjach polsko-żydowskich, to jeśli wyniki wskazywały na to, że stosunkowo mało Polaków rozumiało grozę pochodzenia żydowskiego w czasie wojny, to „Gazeta Wyborcza” uważała za oczywiste, że jest to postulat. Po takich badaniach były pytania do historyków, ludzi mediów, z jasną sugestią, że wiedza jest niedostateczna, że jest oczywiste, że trzeba coś w tej sprawie zrobić.

Z kolei w okolicach 13 grudnia „Gazeta Wyborcza” zamieszczała w latach 90. badanie socjologiczne na temat pamięci o stanie wojennym i trudno było obserwatorowi, czytelnikowi tych gazet zauważyć wyraźną tezę. Raz bowiem była formułowana wyraźniej, a raz mniej wyraźnie, że bardzo duży procent ludzi wspomina stan wojenny jednak jako coś niezbędnego, a Jaruzelskiego jako patriotę. I był z tego wniosek, że proszę bardzo, to vox populi, vox dei, o czym my jeszcze rozmawiamy.

Ze zdziwienia pełzająca amnestią wynikała druga kwestia - zdziwienie Jakuba Karpińskiego dotyczące nielogiczności przeciwników lustracji. W artykule z „Rzeczpospolitej” z 6 marca 1999 roku pod tytułem „Pamięć o przeszłości a lustracja” Jakub Karpiński w swoim felietonie pokazywał, jak przedstawiane sa trzy pozornie sprzeczne ze sobą tezy. Pierwsza: wszyscy zgadzają się, że wspólpraca z komunistyczną służbą była zła. Tak pisze Jakub Karpiński:

W kontrowersjach na temat lustracji rzadko podważa się ocenę, stwierdzająca haniebność współpracy z UB/SB. Warto przypo- 
mnieć teksty z „Gazety Wyborczej” (i innych gazet) z czerwca 1992 roku i ówczesne pasje polityków Unii Demokratycznej. Co złego, zdaniem publicystów i polityków, zrobili wtedy minister Antoni Macierewicz i premier Jan Olszewski? Otóż atakowano ich za to, że umożliwili posądzenia o współpracę z komunistyczną policją polityczną, a więc posądzenia o czyny niesłychanie hańbiące - bez procedur dostatecznie chroniących podejrzanych (Karpiński 1999c).

To był pierwszy moment dyskusji. Skoro posądzenie o współpracę jest czymś strasznym, ergo współpraca była czymś strasznym, więc zrobienie tej lustracji było niepotrzebne. Bardzo często wówczas mówiono „lustracja tak, ale nie taka. Na pewno nie taka”. Pamiętam dobrze takich posłów Unii, którzy tak prawie wykrzykiwali w twarz.

Ale potem nastapiła druga faza, w której zaczęto twierdzić: tak, to prawda, ta lustracja Macierewicza była haniebna, ale czy w ogóle można przeprowadzić lustrację i czy papiery ubeckie są punktem wyjścia. I była tylko jedna odpowiedź - „nie”.

A potem jeszcze, i to też dobrze zauważył Jakub Karpiński, udało się przejść do trzeciej fazy: a może w ogóle lustracja nie jest potrzebna? Po co ją robić? Dzieli ludzi, dzieli życiorysy, małżonek, który przeczyta, że żona go zdradzała, może popełnić samobójstwo, i tak dalej. Czyli od tezy, która mówiła pozornie, że lustracja jest zła, bo współpraca jest zła, tyle dolewano do tego, że tak powiem, kieliszka burgunda wody, że wyszła z tego mętna, różowawa breja.

Kolejna teza, która bardzo bolała Jakuba Karpińskiego, to teza o tym, że wszyscy byli umoczeni. Przypomnę, że to była taka teza, przypominam ja z tekstu Antoniego Pawlaka, niegdyś bardzo aktywnego dziennikarza „Gazety Wyborczej”. I Jakub Karpiński w wywiadzie dla „Nowych Książek” w 2001 roku mówił tak:

W publicystycznych ujęciach okresu PRL słychać nieraz takie tony: przecież wszyscy w tym, co się działo, byli jakoś umoczeni. Można ludzi, którzy tak mówią, posłuchać i uwierzyć im na próbę, ale tylko na próbę. I odpowiedzieć: jeśli wszyscy byli umoczeni, to jeden umoczył paznokcie, a drugi zanurzył się z głową i kopytami” (Karpiński 2001: 4). 
W tym sensie Jakub Karpiński mówił coś bardzo ważnego i dodawal:

[...] obraz PRL zaciera się w społecznej pamięci, w czym ma zapewne udział bardzo łagodna ewolucja Trzeciej Rzeczpospolitej. Wypowiedź premiera Mazowieckiego o grubej linii podobno początkowo rozumiano w ten sposób, że nowe władze z 1989 roku nie chciały mieć nic wspólnego z PRL. Byłby to zamiar ambitny, ale okazał się trudny do realizacji. Przyjęto prawo, kadry, instrukcje PRL, zmieniały one się powoli i wcale nie określono ich grubą linią (Karpiński 2001: 5).

W tym sensie nie było grubej linii, ponieważ, co bardzo dobrze widać przy wyrokach sądowych, można sobie bardzo często wyobrazić, że - to jest taka moja śmiała teza - że słuchając bardzo często uzasadnień werdyktów zazwyczaj uniewinniających rozmaitych komunistycznych niegodziwców, mam wrażenie, że to są ludzie, którzy na przykład zaśmiewają się z dowcipów w tygodniku „Nie”. I wreszcie jeszcze jedno bardzo ważne i dla pewnych osób na pewno dosyć szokujące, ale w tekście Polska po przejściach w „Nowych Książkach” Jakub Karpiński pisze tak:

[...] Komuniści w Polsce wzięli na siebie rolę wykonawców woli radzieckiej. Ich tłumaczenia wyglądają czasem tak, jakby byli w sytuacji Adama Czerniakowa, przewodniczącego samorządu w getcie warszawskim. Były tu jednak znaczne różnice. Adam Czerniakow nie przejął ideologii najeźdźców i jej nie głosił, nie wprowadzał jakiejś miniatury systemu nazistowskiego. Związek komunistów w Polsce z Układem Radzieckim był ściślejszy (Karpiński 2001: 6).

Sami komuniści pozujący dzisiaj na dżentelmenów i ludzi honoru potrafili być bardzo sprawni w przygotowywaniu sytuacji, w której bardzo ciężko ich atakować. Coś tam się odbywało w czarnej skrzynce zamkniętej przed oczami obywateli. Znów wracam do cytatu:

Podkreśleniem tego zamknięcia stało się zniszczenie w ostatnim okresie PRL protokołów obrad biura politycznego na polecenie generała Jaruzelskiego. Pokazano w ten sposób, że te dokumenty 
dotyczą instytucji, która nie życzy sobie, by o niej wiedziano. Rządzący kierowali kolejny apel do społeczeństwa: nie wiedzieliście, co robiliśmy między sobą w grupie rządzącej, i nadal wara wam to oglądać" (Karpiński 2001: 7).

To jest bardzo charakterystyczne, że obrońcy generała Jaruzelskiego powołują się na przykład, że nie ma żadnego rozkazu, który mówi, że wydano rozkaz strzelania w „Wujku” w wypadku Jaruzelskiego czy Kiszczaka. Tylko nie dodaja, że ci, których dotyczy to rozgrzeszenie, bardzo skrupulatnie zadbali, żeby dokumenty z posiedzeń politbiura w'82 roku zostały zniszczone.

Jeszcze jedno. Nie omieszkam, korzystając z okazji, podzielić się cytatem dotyczącym Andrzeja Walickiego. Bo tutaj prowadzący wywiad z „Nowych Książek” stwierdził tak:

Czy okres PRL możemy określić mianem totalitaryzmu? Istnieją rozmaite odpowiedzi, a czasem toczą się spory na ten temat. $\mathrm{Na}$ przykład Andrzej Walicki energicznie protestuje przeciwko takiemu określeniu (Karpiński 2001: 8).

I Jakub Karpiński, znów jestem w stanie sobie wyobrazić na jego twarzy ten angielski uśmiech, mówi tak:

Najkrócej można odpowiedzieć: jaka definicja, takie konkluzje. Niekiedy dobiera się definicję totalitaryzmu do wyników, jakie pragnie się uzyskać. Jeżeli na pojęcie totalitaryzmu nałożymy warunki szczególnie trudne do spełnienia, na przykład zażądamy, aby w takim ustroju panowała ideologia, którą wszyscy bez wyjątku aprobują, to w rezultacie odkryjemy, że totalitaryzmu nigdzie nie było. Nawet Korea Północna nie musi się zmieścić w takiej rygorystycznej definicji, bo może tam jakiś ich Herbert pisze niepodporządkowane utwory, których na razie nie znamy (Karpiński 2001: 8).

To jest, bardzo ważna trzecia teza, ostatnia, najbardziej istotna. Jakub Karpiński przestrzegał, że brak wyrugowania komunizmu z przestrzeni publicznej zatruje demokrację w III RP. Pisał w roku 2001:

Mamy kłopoty z telewizja publiczna, która nie jest pluralistyczna i nazbyt często spełnia funkcje propagandowe na rzecz ośrodków, 
którym udało się zdobyć się w niej wpływy. Tak więc dość potężna instytucja oddziałująca na sprawy społeczne rezygnuje z funkcji kontrolnej wobec sił politycznych. Wiele zastrzeżenia budzi też wymiar sprawiedliwości z kadrą i obyczajami odziedziczonymi po przejściach (Karpiński 2001: 9).

Zakończę takim tekstem, który jest według mnie hołdem dla Jakuba Karpińskiego, ale i smutną refleksją, dlatego że czasami pewne zło wyniszcza coś na dłuższy czas. W tym sensie nawiązuje do noweli Gustawa Herlinga-Grudzińskiego, o tym jak specjalnie zawleczona dżuma do Neapolu, która faktycznie spacyfikowała powstanie ludowe na długie dekady, spowodowała, że Neapol pod władzą Burbonów to państwo, gdzie była głucha pustynia. I Jakub Karpiński pisze:

Kiedy rozważa się skutki stanu wojennego, przychodzi na myśl powiedzenie: od nieszczęść się nie pięknieje. Ten brak piękności warto zestawić z tym, czym była Solidarność z lat '80/'81. Panna S., o której śpiewano piosenki, która miała wdzięk. Pięknie było widać działania w trosce o sprawy wspólne, w patriotyzmie, o zaangażowanie obywatelskie. Można było zobaczyć to piękno na twarzach, zostało utrwalone na fotografiach. Brak piękności lat '80, uwaga - i późniejszych - to jeden ze skutków stanu wojennego. Brzydota jest skutkiem realizacji ideałów leninowskich.

Bibliografia:

/// Karpiński J. 1999a. Czy w ogóle byt tu jakiś komunizm?, „Rzeczpospolita”, nr 5/6, s. D1.

/// Karpiński J. 1999b. Pamiéć o przesz̨tości: PZPR, „Rzeczpospolita”, nr 43, s. 16.

/// Karpiński J. 1999c. Pamiéć o przesztości: lustracja, „Rzeczpospolita”, nr 55, s. 16.

/// Karpiński J. 2001. Polska po præejściach. Z Jakubem Karpińskim rozmawia Andrzej Bernat, „Nowe Książki”, nr 5. 